\title{
Canopy vs. soil effects of shrubs facilitating tree seedlings in Mediterranean montane ecosystems
}

\author{
Gómez-Aparicio, Lorena ${ }^{1 *}$; Gómez, Jose M. ${ }^{1}$; Zamora, Regino ${ }^{1}$ \& Boettinger, Janis L. ${ }^{2}$ \\ ${ }^{1}$ Grupo de Ecología Terrestre, Dpto. Biología Animal y Ecología, Facultad de Ciencias, Universidad de Granada, \\ E-18071, Granada, Spain; ${ }^{2}$ Department of Plants, Soils and Biometeorology, Utah State University, Logan, UT \\ 84322-4820, USA; * Corresponding author; Fax+1 845 6775976; E-mail gomezl@ecostudies.org; Present address: \\ Institute of Ecosystem Studies, 65 Sharon Turnpike, P.O. Box AB, Millbrook, NY, 12545-0129, USA
}

\begin{abstract}
Question: Is the facilitative effect of nurse shrubs on early recruitment of trees mediated by a 'canopy effect' (microclimate amelioration and protection from herbivores), a 'soil effect' (modification of soil properties), or both?

Location: Two successional montane shrublands at the Sierra Nevada Protected Area, SE Spain.

Method: Seedlings of Quercus and Pinus species were planted in four experimental treatments: (1) under shrubs; (2) in open interspaces without vegetation; (3) under shrubs where the canopies were removed; (4) in open interspaces but covering seedlings with branches, mimicking a shrub canopy.

Results: Both effects benefited seedling performance. However, microclimatic amelioration due to canopy shading had the strongest effect, which was particularly pronounced in the drier site. Below-ground, shrubs did not modify soil physical characteristics, organic matter, total $\mathrm{N}$ and $\mathrm{P}$, or water content, but significantly increased available $\mathrm{K}$, which has been shown to improve seedling water-use efficiency under drought conditions.

Conclusions: We propose that in Mediterranean montane ecosystems, characterised by a severe summer drought, pioneer shrubs represent a major safe site for tree early recruitment during secondary succession, improving seedling survival during summer by the modification of both the aboveand below-ground environment.
\end{abstract}

Keywords: Nurse shrub; Positive interaction; Potassium; Removal experiment; Shade.

Nomenclature: Castroviejo et al. (1986-2001) for Quercus and Pinus species, and Molero-Mesa et al. (1992) for shrub species.

\section{Introduction}

Facilitation of seedlings by adult plants underlies successful regeneration of many species under environmental stressful conditions (Niering et al. 1963; Flores \& Jurado 2003), thereby playing a key role in shaping the structure of plant communities. This interaction is due to the habitat-modifying capacity of nurse plants, which can alter its environment both above ('canopy effect') and below-ground ('soil effect') benefiting seedling establishment. The 'canopy effect' involves at least two components: microclimatic amelioration and protection from herbivores. Understorey microclimate is characterized by lower irradiance and air temperature, and consequently lower evapotranspiration demands, than open areas without vegetation (Franco \& Nobel 1988; Valiente-Banuet \& Ezcurra 1991; Callaway 1992; Maestre et al. 2003). On the other hand, canopies of benefactor species can avoid or diminish damage to beneficiary species by the possession of structures that repel prospective herbivores (e.g. thorns, spines), or just by physically hiding them (Wahl \& Hay 1995; Hjältén \& Price 1997; Rebollo et al. 2002). The 'soil effect' involves the modifications that vegetation produces on chemical, physical and biological soil properties. Many studies have shown that woody species can increase soil nutrients and organic matter because of the accumulation of litter beneath their canopies (e.g. Soriano \& Sala 1986; Aguiar \& Sala 1994), trapping of windblown particles (Escudero et al. 1985; DeSoyza et al. 1997), or symbiotic associations with $\mathrm{N}$-fixing micro-organisms (Chapin et al. 1994; Alpert \& Mooney 1996). The 'canopy effect' and the 'soil effect' are also interrelated. Lower radiation under nurse plants reduce soil temperature and evaporative water losses, whereas higher organic matter content improves soil water retention, thereby causing soil moisture and rates of litter decomposition to be higher under nurses than in open areas (Joffre \& Rambal 1993; Cornejo et al. 1994; Aguilera et al. 1999).

The importance of nurse-plant interactions varies with the physical and biological environment, as well as the physiological and demographic traits of the interacting species (Bertness \& Callaway 1994; Callaway \& Walker 1997). Likewise, the relative importance of canopy effects vs. soil effects could vary strongly depending on the characteristics of the system and the species considered. However, most studies aimed at elucidating the mechanisms underlying plant facilitation have been conducted in ecosystems characterised 
by a distinct patchy pattern, such as savannas and arid ecosystems (Scholes \& Archer 1997; Aguiar \& Sala 1999). In these systems, woody plants facilitate vegetation growing beneath their canopies (mainly herbaceous species) by ameliorating the physical environment and specially by increasing soil fertility (Jackson et al. 1990; Callaway et al. 1991; Belsky 1994; Pugnaire et al. 1996; Tirado 2003). Far fewer studies have examined mechanisms enabling nurse relationships in other ecosystems and, in particular, between woody species (but see Kitzberger et al. 2000 and Rudgers \& Maron 2003).

Recent experiments have shown that pioneer shrubs facilitate tree seedling survival and growth during secondary succession in Mediterranean mountains (GómezAparicio et al. 2004). However, the specific mechanisms involved and the extent to which they operate in different environments and for different interacting species are still unknown. Shade appears to be a necessary condition for seedling establishment of several Mediterranean woody species (Gómez 2004; Castro et al. 2004a; Gómez-Aparicio et al. 2005). In addition, the habitat structure, topography, and inherent soil variability of Mediterranean montane forests may be more complex than the two-phase configuration of savannas and arid ecosystems, possibly obscuring potential plantinduced changes in soil properties. Therefore, in these systems, the 'soil effect' of shrubs in facilitative interactions may be secondary to the 'canopy effect'. The main objective of this study was to determine the relative importance of canopy and soil effects in the facilitation of tree seedlings by pioneer shrubs. Specifically, our main questions were: 1 . What is the net effect of pioneer shrubs on tree seedling survival and growth during secondary succession? 2. Can the relative importance of the canopy effect vs. the soil effect be elucidated? 3. Do the mechanisms of facilitation vary depending on the sites and species considered?

\section{Material and Methods}

\section{Study sites}

The study was conducted at two sites in the Sierra Nevada Protected Area (Granada, SE Spain). Sites were chosen because of their contrasting environmental characteristics, since although both are under post-fire secondary succession, one site is a Mediterranean highmountain mesic system whereas the other is a mediummountain xeric system. The first site is located at 1800$1850 \mathrm{~m}$ a.s.l. on the northwestern slope of Loma de Panaderos (Trevenque area, $37^{\circ} 5^{\prime} \mathrm{N}, 3^{\circ} 28^{\prime} \mathrm{W}$ ). The soil parent material is colluvium and residuum derived dominantly from limestone, with slopes ranging from $5^{\circ}$ to $15^{\circ}$.
The original Pinus sylvestris var. nevadensis forest was burned in 1983. Since then, the area has been recolonized by different shrub species, mainly Salvia lavandulifolia ssp. vellerea (Lamiaceae), an evergreen shrub that reaches a maximum of $50 \mathrm{~cm}$ high and $2 \mathrm{~m}$ in diameter. Inter-shrub spaces are ca. 1-3 $\mathrm{m}$ in diameter. The climate is subhumid Mediterranean, with a mean precipitation of 846 mm. $\mathrm{a}^{-1}$ (1991-2002; data from a meteorological station at the Cortijuela Botanical Garden). Summers are hot and dry. The mean minimum temperature in the coldest month (January) is $-0.9^{\circ} \mathrm{C}$, the mean maximum of the hottest month (July) is $29.0^{\circ} \mathrm{C}$, and the mean annual temperature is $11.5^{\circ} \mathrm{C}$.

The second site is located at $1450 \mathrm{~m}$ a.s.l. on the southern slope of Loma de Lanjarón ( $36^{\circ} 56^{\prime} \mathrm{N}, 3^{\circ} 29^{\prime}$ $\mathrm{W})$. The soil parent material is colluvium and residuum derived from mica schist, with slopes ranging between $15^{\circ}$ and $20^{\circ}$. It was formerly a Pinus halepensis afforestation that was burned in 1985. Currently, the site is occupied by an early successional community dominated by the perennial shrubs Ulex parviflorus (Fabaceae) and Santolina canescens (Asteraceae). Both species reach 50-100 $\mathrm{cm}$ mean height and 1-2 m diameter; individuals are separated by less than $2 \mathrm{~m}$. The climate is dry Mediterranean (548 mm. $\mathrm{a}^{-1}$, 1991-2002; data from the Lanjarón Meteorological Station). The mean minimum temperature in the coldest month (January) is $3.3^{\circ} \mathrm{C}$, the mean maximum of the hottest month (July) is $29.4^{\circ} \mathrm{C}$, and the mean annual temperature is $15.1^{\circ} \mathrm{C}$. Ungulates at both study areas are mainly represented by Spanish ibex Capra pyrenaica.

\section{Experimental design}

In February 2000 one experiment per site was carried out. The basic design consisted of planting oneyear-old tree seedlings in four treatments: (1) under the canopy of shrub species (Shrub treatment); (2) in open interspaces without vegetation (Open treatment); (3) under shrubs where the canopies were removed by clipping the stems just above the ground (Clipped Canopy treatment), and (4) in open interspaces without vegetation but covering seedlings with the branches removed in the Clipped Canopy treatment, mimicking a shrub canopy (Mimicked Canopy treatment). In each site, we chose to plant seedlings of tree species that would naturally occupy the area, resulting in some differences in species planted. However, one common species (Quercus ilex) was planted at both sites as a betweensite control. We used the most abundant shrub species in each site as nurse plants, choosing shrubs of similar morphology (short stature) in order to minimize intersite variability due to different shrub identity. Seedlings of Quercus ilex, Pinus nigra ssp. salzmanii and Pinus 
sylvestris var. nevadensis were planted in Loma de Panaderos, and Salvia lavandulifolia ssp. vellerea was used as the nurse plant. Experimental seedlings were distributed according to a randomized block-design in three $2000-\mathrm{m}^{2}$ plots separated by about $200 \mathrm{~m}$. In Loma de Lanjarón, we planted Quercus ilex and Pinus halepensis seedlings in one $2000-\mathrm{m}^{2}$ plot, using Ulex parviflorus and Santolina canescens as nurse plants. In each plot, 50 seedlings per tree species and treatment were planted, a total of 1800 seedlings in Loma de Panaderos and 800 in Loma de Lanjarón. In all cases, planting holes were dug $40 \mathrm{~cm}$ deep with a mechanical auger having a $20-\mathrm{cm}$ diameter bit, with no further cultivation around the plants. Seedlings were supplied by the Junta de Andalucía (Granada, Spain) and grown in nurseries under similar conditions.

\section{Abiotic characterization of experimental treatments}

Abiotic environmental conditions in each experimental treatment were characterized by measuring above- and below-ground microclimate, soil water content, and soil physical and chemical characteristics. Microclimatic conditions were measured with HOBO H8 sensors (Onset Computer Corporation, Massachusetts, USA) located in six sampling stations per microhabitat distributed randomly within each study area. They recorded air temperature $\left(T_{a}\right)$, soil temperature at $5 \mathrm{~cm}$ depth $\left(T_{s}\right)$, global radiation $(R)$ and relative humidity $(R H)$ every 15 minutes during three summer cloudless days. $R H$ and $T_{a}$ values were used to calculate the vapour pressure deficit (VPD) as an indicator of the atmospheric evapotranspiration demand (Pearcy et al. 1989). Volumetric soil water content was recorded using ThetaProbe sensors (Delta-T Devices Ltd., Cambridge, UK). Measurements were made $15-16$ July 2000 in 15 sampling points per microhabitat at $20 \mathrm{~cm}$ depth, because seedlings are considered to have the majority of their roots in this upper soil layer (authors' pers. obs.). Although we made no abiotic measures in 2001, climatic data showed that both years had a total of summer precipitation ( $2 \mathrm{~mm}$ in 2000 and 10 $\mathrm{mm}$ in 2001) well below the average $(47 \mathrm{~mm}$ average, 1991-2002). Thus, we can assume that abiotic conditions reported here represent extreme drought conditions in the study zones during the two years of the experiment.

To analyse the physical and chemical soil characteristics we sampled the upper $15 \mathrm{~cm}$ of the soil using a standard bucket auger. Ten soil samples were collected from each treatment, placed in plastic bags and transported to the laboratory. Air-dry soils were sieved and the $<2-\mathrm{mm}$ fraction was analysed for routine chemical and physical properties (Anon. 1994) at the Food and Agriculture Laboratory of Granada. Soils in Open and Shrub treatments at both study sites were sampled and analysed the first year of study, whereas soils in the Mimicked and Clipped Canopy treatments were sampled and analysed in the second year. Because there was unexplainable variation in some characteristics of soils sampled at different times and analysed in different batches we only used data from the Open and Shrub treatments for statistical comparisons. This irregularity nevertheless did not significantly affect the interpretation of our results (see Results and Discussion below).

\section{Seedling measurements}

Seedlings were counted twice a year between February 2000 and February 2002, once after summer (October) and once after winter (April). For each seedling we recorded: (1) survival, together with the most likely cause of mortality; (2) height, from the soil surface to the apical bud; and (3) herbivory damage, estimated as the percentage of browsed shoots in relation to the total number of shoots. We calculated the accumulated Relative Height Growth $(R H G)$ during the whole study period as $\left(\ln H_{2}-\ln H_{1}\right) /\left(t_{2}-t_{1}\right)$, where $H_{2}$ and $H_{1}$ represents the final and initial heights, and $t_{2}-t_{1}$ the time elapsed between measurements.

\section{Data analysis}

Differences in cumulative seedling survival were analysed, for each study site, by Generalized Logit Models (Proc CATMOD, SAS; Anon. 2002) using the maximum likelihood as estimation method (Stokes et al. 1995). We included as independent variables the treatment, species, and block in Loma de Panaderos, and the treatment, species, and nurse plant in Loma de Lanjarón. Differences between levels of significant factors were explored by partial $\chi^{2}$ - tests after correcting by Bonferroni adjustment at $\alpha<0.05$ (Cabin \& Mitchell 2000). To examine between-treatment differences in seedling RHG, we used General Linear Models (Proc GLM, SAS, Anon. 2002). One-way ANOVAs were performed for each combination of seedling species and study site, considering only treatments with more than one surviving seedling at the end of the experiment (i.e. Clipped canopy was excluded for P. nigra and $P$. sylvestris in Loma de Panaderos, and Clipped canopy and Open for $Q$. ilex in Loma de Lanjarón). We did not analyse differences in RHG among blocks or nurse plants due to the low number of surviving seedlings.

Between-treatment differences in abiotic conditions were analysed using one-way ANOVAs (Proc GLM, SAS 2002). For air temperature $\left(T_{a}\right)$, vapor pressure deficit (VPD), global radiation $(R)$ and soil temperature $\left(T_{s}\right)$ we considered as dependent variables the mean values recorded per sample point throughout the three 
days, in order to avoid pseudoreplication. Data used in the ANOVAs were tested for normality and homoscedasticity and transformed when necessary. Throughout this paper, means are shown $\pm 1 \mathrm{SE}$.

\section{Results}

\section{Abiotic characterization of experimental treatments}

All the microclimatic variables differed significantly among treatments at both study sites (Table 1). Mean air temperature, radiation and vapour pressure deficit were in all cases higher in Open and Clipped Canopy than in Shrubs and Mimicked Canopy treatments (Table 1). Soil temperature was also lower in Shrubs and Mimicked Canopy than in the other two treatments (Table 1). However, there were no differences in soil water content among microhabitats, with values ranging from $8-10 \%$ in Loma de Panaderos and 1-3\% in Loma de Lanjarón (Table 1).

In relation to soil chemical and physical properties, treatments differed significantly only in $\mathrm{pH}$ and available K (Table 2). The $\mathrm{pH}$ was higher in the Shrub (7.58 $\pm 0.08)$ than in the Open treatment $(7.19 \pm 0.04)$ in Loma de Panaderos, although differences were relatively small, both $\mathrm{pH}$ values being very slightly alkaline. Available $\mathrm{K}$ was also much higher under $S$. lavandulifolia than in Open $(F=14.25, \mathrm{df}=1 ; 8, p=$ $0.001)$. The same pattern was found in Loma de Lanjarón, where available $\mathrm{K}$ under $U$.parviflorus and, especially, under $S$. canescens was higher than in the Open treatment $(F=7.81, \mathrm{df}=1 ; 8, p=0.012$ and $F=$
18.91, $\mathrm{df}=1 ; 8, p=0.0004$, respectively).

\section{Seedling measurements}

Of the initial seedlings planted, only $21.9 \%$ survived in Loma de Panaderos and $13.8 \%$ in Loma de Lanjarón until the end of the experiment. About $90 \%$ of mortality occurred during the first summer at both study sites, mainly due to summer drought (Fig. 1). Cumulative seedling survival differed among treatments in the two study sites (Table 3). The highest survival occurred in the Shrub and the lowest in the Open treatment, survival increasing by a factor of two in Loma de Panaderos (39.3\% in Shrub vs. $18.9 \%$ in Open) and by more than an order of magnitude in Loma de Lanjarón (25.6\% in Shrub vs. 2.0\% in Open). Survival in the Mimicked Canopy and Clipped Canopy treatments was generally intermediate between the Open and Shrub treatments (Fig. 1).

Survival differed significantly between tree species at both study sites (Table 3). In Loma de Panaderos, survival of $Q$. ilex seedlings (48.0\%) was over four times higher than P. nigra survival (10.9\%) and more than eight times higher than $P$. sylvestris survival (5.7\%). In Loma de Lanjarón, $P$. halepensis survival (19.2\%) was more than two times higher than $Q$. ilex survival (8.2\%). When compared across sites, $Q$. ilex survival was much higher in moister Loma de Panaderos than in Loma de Lanjarón. Furthermore, the increment in survival caused by shrubs in comparison to Open was much higher in drier Loma de Lanjarón (from 0\% to $20.5 \%$ ) than in Loma de Panaderos (from $25.2 \%$ to 70.9\%; Fig. 1).

Table 1. Microclimatic conditions $(n=6)$ and soil volumetric water content $(n=10)$ measured in the experimental treatments (means $\pm 1 \mathrm{SE})$. Radiance is expressed as percentages of radiance in the Open treatment. The results of the tests for Loma de Panaderos are: $F=26.97, \mathrm{df}=3 ; 20, p<0.0001$ for $T_{a} ; F=47.45, \mathrm{df}=3 ; 20, p<0.0001$ for $R ; F=36.57, \mathrm{df}=3 ; 20, p<0.0001$ for VPD; $F=18.17$, $\mathrm{df}=3 ; 20, p<0.0001$ for $T_{s}$; and $F=1.57, \mathrm{df}=3 ; 36, p=0.21$ for $V W C$. The results for Loma de Lanjarón are: $F=13.94, \mathrm{df}=6 ; 35$, $p<0.0001$ for $T_{a} ; F=14.01, \mathrm{df}=6 ; 35, p<0.0001$ for $R ; F=13.67, \mathrm{df}=6 ; 35, p<0.0001$ for $V P D ; F=11.89, \mathrm{df}=6 ; 35, p<0.0001$ for $T_{s}$; and $F=1.52$, df $=6,63, p=0.18$ for $V W C$. Different letters show significant differences at $\alpha<0.05$ (after Bonferroni correction) for the same variable and study site.

\begin{tabular}{|c|c|c|c|c|c|}
\hline \multirow[b]{2}{*}{ Treatment } & \multicolumn{3}{|c|}{ Above-ground } & \multicolumn{2}{|c|}{ Below-ground } \\
\hline & $T_{a}\left({ }^{\circ} \mathrm{C}\right)$ & $R(\%)$ & $V P D(\mathrm{MPa})$ & $T_{s}\left({ }^{\circ} \mathrm{C}\right)$ & $V W C(\%)$ \\
\hline \multicolumn{6}{|l|}{ Loma de Panaderos } \\
\hline Salvia lavandulifolia & $29.51 \pm 0.31 \mathrm{a}$ & $57.1 \pm 0.98 \mathrm{a}$ & $2.94 \pm 0.04 \mathrm{a}$ & $23.3 \pm 0.21 \mathrm{a}$ & $9.31 \pm 0.40 \mathrm{a}$ \\
\hline Salvia lavandulifolia Mimicked Canopy & $32.73 \pm 0.35 b$ & $69.7 \pm 2.56 b$ & $3.34 \pm 0.05 b$ & $29.9 \pm 0.22 b$ & $8.30 \pm 0.22 \mathrm{a}$ \\
\hline Salvia lavandulifolia Clipped Canopy & $39.51 \pm 0.62 c$ & $94.8 \pm 0.44 \mathrm{c}$ & $6.02 \pm 0.22 c$ & $28.8 \pm 0.30 \mathrm{c}$ & $8.48 \pm 0.34 a$ \\
\hline Open & $38.73 \pm 0.51 \mathrm{c}$ & $99.1 \pm 0.64 c$ & $5.78 \pm 0.14 c$ & $32.4 \pm 0.33 \mathrm{~d}$ & $8.73 \pm 0.47 a$ \\
\hline \multicolumn{6}{|l|}{ Loma de Lanjarón } \\
\hline Ulex parviflorus & $30.67 \pm 0.21 \mathrm{a}$ & $38.7 \pm 0.78 \mathrm{a}$ & $2.79 \pm 0.05 a$ & $28.1 \pm 0.25 a$ & $1.92 \pm 0.43 \mathrm{a}$ \\
\hline Santolina canescens & $32.34 \pm 0.42 \mathrm{a}$ & $62.2 \pm 0.99 \mathrm{~b}$ & $3.24 \pm 0.08 b$ & $29.8 \pm 0.35 a$ & $1.71 \pm 0.34 \mathrm{a}$ \\
\hline Ulex parviflorus Mimicked Canopy & $35.07 \pm 0.55 \mathrm{ab}$ & $50.8 \pm 2.56 \mathrm{c}$ & $3.06 \pm 0.11 \mathrm{ab}$ & $32.8 \pm 0.31 b$ & $1.81 \pm 0.21 \mathrm{a}$ \\
\hline Santolina canescens Mimicked Canopy & $36.31 \pm 0.54 b$ & $72.8 \pm 2.72 \mathrm{~d}$ & $4.33 \pm 0.12 \mathrm{c}$ & $33.0 \pm 0.40 \mathrm{~b}$ & $1.37 \pm 0.20 \mathrm{a}$ \\
\hline Ulex parviflorus Clipped Canopy & $43.46 \pm 0.94 \mathrm{c}$ & $96.6 \pm 0.78 \mathrm{e}$ & $7.04 \pm 0.38 \mathrm{~d}$ & $35.9 \pm 0.50 \mathrm{c}$ & $1.18 \pm 0.33 a$ \\
\hline Santolina canescens Clipped Canopy & $43.11 \pm 0.95 c$ & $95.6 \pm 0.54 \mathrm{e}$ & $6.91 \pm 0.36 \mathrm{~d}$ & $36.9 \pm 0.63 c$ & $1.95 \pm 0.36 \mathrm{a}$ \\
\hline Open & $42.72 \pm 0.77 \mathrm{c}$ & $99.3 \pm 0.45 \mathrm{e}$ & $5.94 \pm 0.24 \mathrm{~d}$ & $35.6 \pm 0.51 \mathrm{c}$ & $2.39 \pm 0.32 \mathrm{a}$ \\
\hline
\end{tabular}


Table 2. Summary of soil physical and chemical characteristics in Shrub and Open treatments. For each study site, variables that significantly differed between treatments at $\alpha<0.05$ (after Bonferroni correction) are shown in bold.

\begin{tabular}{|c|c|c|c|c|c|}
\hline \multirow[b]{2}{*}{ Variable* } & \multicolumn{2}{|c|}{ Loma de Panaderos } & \multicolumn{3}{|c|}{ Loma de Lanjarón } \\
\hline & Open & Salvia lavandulifolia & Open & Ulex parviflorus & Santolina canescens \\
\hline Clay $(\%)$ & $30.72 \pm 1.02$ & $31.02 \pm 1.01$ & $7.40 \pm 0.27$ & $8.50 \pm 0.31$ & $7.90 \pm 0.31$ \\
\hline $\mathrm{AWC}(\%)$ & $18.19 \pm 1.94$ & $23.98 \pm 0.89$ & $11.67 \pm 0.45$ & $12.26 \pm 0.52$ & $12.66 \pm 0.49$ \\
\hline $\mathrm{pH}$ & $7.19 \pm 0.04$ & $7.58 \pm 0.08$ & $6.55 \pm 0.09$ & $6.74 \pm 0.08$ & $6.87 \pm 0.06$ \\
\hline $\mathrm{CEC}\left(\mathrm{cmol}_{\mathrm{c}} / \mathrm{kg}\right)$ & $19.12 \pm 1.38$ & $17.49 \pm 0.67$ & $8.87 \pm 0.47$ & $9.50 \pm 0.36$ & $9.71 \pm 0.26$ \\
\hline $\mathrm{OM}(\%)$ & $4.84 \pm 0.47$ & $5.46 \pm 0.33$ & $1.62 \pm 0.32$ & $2.11 \pm 0.17$ & $1.77 \pm 0.14$ \\
\hline $\mathrm{N}(\%)$ & $0.29 \pm 0.02$ & $0.31 \pm 0.02$ & $0.11 \pm 0.01$ & $0.13 \pm 0.01$ & $0.12 \pm 0.01$ \\
\hline $\mathrm{P}(\mathrm{mg} / \mathrm{kg})$ & $4.10 \pm 0.41$ & $6.10 \pm 0.78$ & $1.80 \pm 0.39$ & $1.40 \pm 0.16$ & $1.40 \pm 0.22$ \\
\hline $\mathrm{K}(\mathrm{mg} / \mathrm{kg})$ & $138.00 \pm 10.52$ & $204.05 \pm 15.36$ & $88.00 \pm 10.91$ & $127.00 \pm 11.03$ & $183.50 \pm 21.49$ \\
\hline
\end{tabular}

There were significant differences in the response of tree species to treatments in Loma de Panaderos (significant Treatment $\times$ Species interaction term; Table 3 ) but not in Loma de Lanjarón. Thus, survival of Q. ilex in Loma de Panaderos was boosted by the Mimicked and the Clipped Canopy treatments, survival of P. nigra only by the Mimicked Canopy treatment, and survival of $P$. sylvestris by none of the treatments (Fig. 1). Finally, there were significant between-block differences in seedling survival in Loma de Panaderos (Table $3)$. No between-nurse plant differences in seedling survival appeared in Loma de Lanjarón (Table 3).

$R H G$ was very low in all cases, not surpassing 0.6 $\mathrm{mm} / \mathrm{year}$ for any species and treatment combination. It differed between treatments only for $Q$. ilex in Loma de Panaderos $(F=4.946, \mathrm{df}=3, p=0.003)$, being higher in

Table 3. Summary of the contingency analysis for seedling survival at the end of the experiment.

\begin{tabular}{lccc}
\hline Study site /Factor & df & $\chi^{2}$ & $p$ \\
\hline Loma de Panaderos & & & \\
Treatment & 3 & 71.68 & $<0.0001$ \\
$\quad$ Species & 2 & 224.92 & $<0.0001$ \\
Block & 2 & 25.34 & $<0.0001$ \\
Treatment $\times$ Species & 6 & 18.03 & 0.0062 \\
Treatment $\times$ Block & 6 & 9.29 & 0.1577 \\
Species $\times$ Block & 4 & 6.39 & 0.1717 \\
Model & 23 & 351.05 & $<0.0001$ \\
Loma de Lanjarón & & & \\
Treatment & 3 & 43.27 & $<0.0001$ \\
$\quad$ Species & 1 & 11.11 & 0.0009 \\
Nurse & 1 & 0.55 & 0.4568 \\
Treatment $\times$ Species & 3 & 8.50 & 0.2479 \\
Treatment $\times$ Nurse & 3 & 1.71 & 0.6353 \\
Species $\times$ Nurse & 3 & 1.43 & 0.2315 \\
Model & 12 & 62.89 & $<0.0001$ \\
\hline
\end{tabular}

Shrub (0.19 $\left.\pm 0.01 \mathrm{~mm} \cdot \mathrm{a}^{-1}\right)$ and Mimicked Canopy $\left(0.09 \pm 0.01 \mathrm{~mm} . \mathrm{a}^{-1}\right)$ than in the Clipped Canopy $(0.04 \pm$ $\left.0.02 \mathrm{~mm} \cdot \mathrm{a}^{-1}\right)$ and the Open $\left(0.04 \pm 0.01 \mathrm{~mm}^{-\mathrm{a}^{-1}}\right)$ treatments. The percentage of seedlings damaged by ungulates was lower than $4 \%$ in all study years and sites, the damage being homogeneously distributed between treatments.

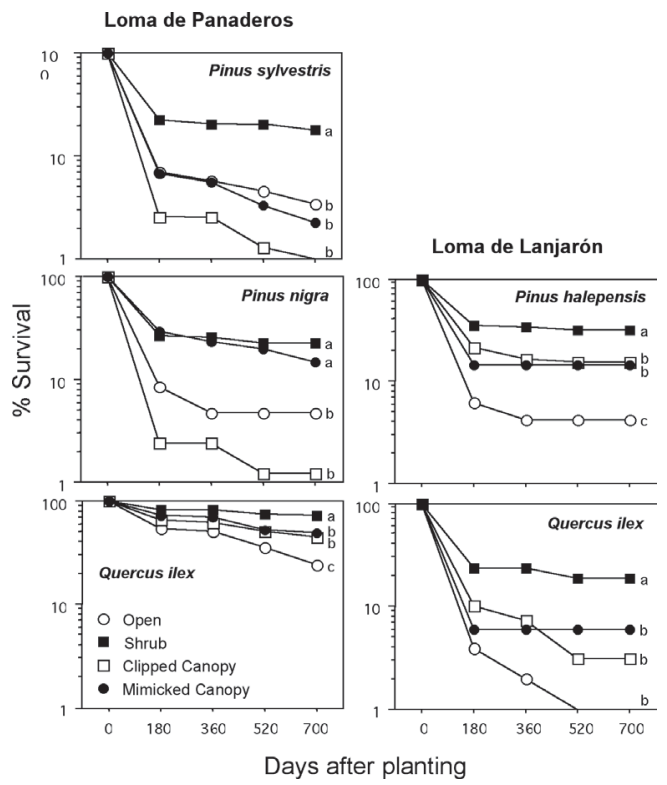

Fig. 1. Survival of tree seedlings planted in the four experimental treatments. Different letters show significant differences at $\alpha<0.05$ (after Bonferroni correction) in accumulated survival at the end of the experiment. 


\section{Discussion}

\section{Net effect of shrubs over seedling performance}

Our results have shown that pioneer shrubs facilitate early recruitment of tree seedlings in the Mediterranean mountains, thereby showing the relevance that positive interactions play during secondary succession in these type of ecosystems (see also Maestre et al. 2001, 2003; Castro et al. 2004b; Gómez-Aparicio et al. 2004). Furthermore, the higher positive effect of shrubs in Loma de Lanjarón than in Loma de Panaderos (both when considering all tree species pooled and just for $Q$. ilex) agrees with the conceptual model that predicts the importance of positive interactions to increase with abiotic stress (Bertness \& Callaway 1994; Holmgren et al. 1997). Thus, in Loma de Lanjarón, the lower altitude, southern aspect, steeper slope, coarser soil textures and lower available water capacity could have all contributed to greater drought stress than at Loma de Panaderos, resulting in higher seedling mortality during the critical first summer. Between-site differences in the positive effect of shrubs could also have been influenced by differences in the species of the nurse plants. However, as shrubs at both sites had similar effects over soil and microclimatic characteristics, it is likely that inter-site differences were mainly derived from their contrasting abiotic conditions. Differences in facilitation importance in relation to stress level were also found between tree species in the same study site. The higher the percentage of total mortality for a tree species, the more shrubs boosted survival when compared to open areas. Therefore, both inter- and intra-sites differences in the effect of shrubs on survival were highly linked both to the 'absolute' stress level of the system (or stress measured in abiotic terms) and to the 'functional' stress level (or stress measured as species-specific responses).

\section{Relative importance of soil vs. canopy effects}

Seedling survival was higher in Shrub than in any other treatment at both study sites, whereas survival in the Mimicked and Clipped Canopy treatments was generally intermediate. These findings suggest that there was not a net competitive effect, neither above- nor below-ground, between shrubs and tree seedlings. On the contrary, both the canopy effect and the soil effect were positive and thereby responsible for the facilitative effect that shrubs had on tree seedlings (see CarrilloGarcía et al. 2000 for a similar result). Moreover, both effects together were necessary to improve seedling survival in cases of high 'functional' stress levels. Hence, when seedling mortality was greater than or equal to $90 \%$, as was the case for $P$. sylvestris in Loma de
Panaderos and Q. ilex in Loma de Lanjarón, only whole shrubs functioned as safe sites for recruitment.

Nevertheless, our canopy manipulation experiments suggested that the modification of soil physical and chemical properties by shrubs (soil effect) exerted a lower benefit over seedling survival and growth than the canopy effect. In fact, at both study sites seedling survival was generally lower when shrub canopies were removed (Clipped Canopy treatment) than when the influence of shrubs on soil properties was 'eliminated' (Mimicked Canopy treatment). This result agrees with the limited effect of nurse plants on soil properties found in this study. The presence of pioneer shrubs did not modify soil physical characteristics such as texture or available water capacity, nor increase organic matter accumulation. Soil nutrient capacity (CEC, $\mathrm{N}$ and $\mathrm{P}$ ) was also similar, despite one of the nurse plants considered, Ulex parviflorus, was a nitrogen-fixing legume. In general, soil enrichment by legumes has been shown to have beneficial effects on neighbours in nutrient-poor environments (see Shumway 2000 and references therein), as is the case of Mediterranean systems (Gallardo 2001). However, Ulex parviflorus shows a low rate of $\mathrm{N}$-fixation, together with an important accumulation of $\mathrm{N}$ in standing necromass (Huesca et al. 1998), which could help its minimal effect on soil fertility. The absence of a stronger soil effect of pioneers shrubs, in contrast to results reported for other latesuccessional systems like savannas, can be caused by several non-exclusive characteristics of the Mediterranean systems studied, such as (1) a higher density of shrubs, which determines a lower capacity of resource nucleation per nurse shrub; (2) their lower age and size, which implies less time to affect abiotic conditions; and (3) lower inter-patch distance, which diminishes probabilities of finding below-ground open spaces out of reach of any root system.

However, nurse shrubs effectively modified one soil property, available $\mathrm{K}$, being in all cases higher under shrubs than in open interspaces. Potassium seems to increase plant resistance to drought, mainly due to osmotic adjustments and a reduction in transpiration rates, which in turn involves a higher water-use efficiency (Bradbury \& Malcom 1977; van den Driessche 1991; Egilla et al. 2001). Despite its potential benefit, this nutrient has never been highlighted when analysing facilitation mechanisms by nurse plants, with most studies focusing on the modification of soil nitrogen as the main nutrient-related facilitation mechanism (Pugnaire et al. 1996; Moro et al. 1997; Carrillo-García et al. 2000). In this sense, the increase in soil potassium caused by shrubs could be an overlooked but relevant soil effect on facilitation in systems where summer drought constitutes the main limiting factor for plant survival in the field. 
The canopy effect due to microclimate amelioration was the main mechanism enhancing seedling survival and growth (see also Valiente-Banuet \& Ezcurra 1991; Valiente-Banuet et al. 1991; Greenlee \& Callaway 1996; and Maestre et al. 2001). Lower air and soil temperatures, radiation and vapor pressure deficit measured below shrub canopies in comparison to open areas reduced leaf temperature and transpiration losses, consequently inducing a more favourable water balance in tree seedlings. This array of modifications could be critical for seedlings to withstand the summer drought, consequently suggesting that shade constitutes a key facilitative mechanism in Mediterranean systems, even without improving soil water conditions (as it occurred in our study; Holmgren et al. 1997; Domingo et al. 1999). Protection against herbivores, another potential benefit of being covered by shrubs, could not be explored, since ungulates injured very few seedlings presumably due to both the small sapling height (and consequent difficulty in being found) and the low ungulate densities in the study areas.

To summarize, we proposed that, although canopy shading appeared as the main factor involved in the interaction under study, modification of potassium content by shrubs could also contribute to enhanced tree seedling survival during the dry and hot Mediterranean summers. Therefore, in scenarios where drought constitutes the main factor limiting secondary succession, pioneer shrubs can represent the only safe sites for woody species recruitment thanks to their widespread capacity of habitat modification both above- and below-ground.

Acknowledgements. We are especially grateful to Jose Antonio Hódar, Jorge Castro and Sergio de Haro for their contributions in the design and revisions of the experiment. We thank the Consejería de Medio Ambiente (Junta de Andalucía) and the Direction of the Sierra Nevada National Park for permission for field work. Constructive suggestions from Thomas Kitzberger and two anonymous referees improved the final version of the manuscript. This study was supported by a PFPU-MECD grant to L. Gómez-Aparicio, and projects FEDER 1FD97-0743-CO3-02 and REN 2000-3176-E from MCYT.

\section{References}

Anon. 1994. Métodos oficiales de análisis. Vol. III. Ministerio de Agricultura, Pesca y Alinetación, Madrid, ES.

Anon. 2002. SAS/STAT user's guide. Version 8.2. SAS Institute, Cary, NC, US.

Aguiar, M.R.\& Sala, O.E. 1994. Competition, facilitation, seed distribution, and the origin of patches in a Patagonian steppe. Oikos 70: 26-34.

Aguiar, M.R.\& Sala, O.E. 1999. Patch structure, dynamics and implications for the functioning of arid ecosystems. Trends Ecol.Evol. 14: 273-277.

Aguilera, L.E., Gutiérrez, J.R. \& Meserve,P.L. 1999. Variation in soil micro-organisms and nutrients underneath and outside the canopy of Adesmia bedwellii (Papilionaceae) shrubs in arid coastal Chile following drought and above average rainfall. J. Arid Environ. 42: 61-70.

Alpert, P. \& Mooney, H.A. 1996. Resource heterogeneity generated by shrubs and topography on coastal sand dunes. Vegetatio 122: 83-93.

Belsky, A.J. 1994. Influences of tree on savanna productivity: test of shade, nutrients, and tree-grass competition. Ecology 75: 922-932.

Bertness, M.D. \& Callaway, R.M. 1994. Positive interactions in communities. Trends Ecol. Evol. 5: 191-193.

Bradbury, I.K. \& Malcom, D.C. 1977. The effect of phosphorus and potassium on transpiration, leaf diffusive resistance and water-use efficiency in Sitka spruce (Picea sitchensis) seedlings. J. Appl. Ecol. 14: 631-641.

Cabin, R.J. \& Mitchell, R.J. 2000. To Bonferroni or not to Bonferroni: when and how are the questions. Bull. Ecol. Soc. Am. 79: 246-248.

Callaway, R.M. 1992 Effect of shrubs on recruitment of Quercus douglasii and Quercus lobata in California. Ecology 73: 2118-2128.

Callaway, R.M. \& Walker, L.R. 1997. Competition and facilitation: a synthetic approach to interactions in plant communities. Ecology 78: 1958-1965.

Callaway, R.M., Nadkarni, N.M. \& Mahall, B. 1991. Facilitation and interference of Quercus douglasii on understory productivity in central California. Ecology 72: 1484-1499.

Carrillo-García, A., Bashan, Y. \& Bethlenfalvay, G.J. 2000. Resource-island soils and the survival of the giant cactus, cardon, of Baja California Sur. Plant Soil 218: 207-214.

Castro, J., Zamora, R., Hódar, J.A. \& Gómez, J.M. 2004a. Seedling establishment of a boreal tree species (Pinus sylvestris) at its southernmost distribution limit, consequences of being in a marginal Mediterranean area. J. Ecol. 92: 266-277.

Castro, J., Zamora, R., Hódar, J.A., Gómez, J.M. \& GómezAparicio, L. 2004b. Benefits of using shrubs as nurse plants for reforestation in Mediterranean mountains: a 4-year study. Rest. Ecol 12: 352-358.

Castroviejo, S., Laínz, M., López-González, G., Montserrat, P., Muñoz-Garmendia, F., Paiva, J. \& Villar, I. (eds). 19862001. Flora Iberica. CSIC, Madrid, ES.

Chapin, F.S., Walker, L.R., Fastie, C.L. \& Sharman, L.C. 1994. Mechanisms of primary succession following deglaciation at Glacier Bay, Alaska. Ecol. Monogr. 64: 149-175.

Cornejo, F.H., Varela, A. \& Wright, S.J. 1994. Tropical forest litter decomposition under seasonal drought: nutrient release, fungi and bacteria. Oikos 70: 183-190.

DeSoyza, A.G., Whitford, W.G., Martinez-Meza, E. \& Van Zee,J.W. 1997. Variation in creosotebush (Larrea tridentata) canopy morphology in relation to habitat, soil fertility and associated annual plant communities. Am. Midl. Nat. 137: 13-26.

Domingo, F., Villagarcía, L., Brenner, A.J. \& Puigdefábregas, J. 1999. Evapotranspiration model for semi-arid shrub- 
lands tested against data from SE Spain.Agric.For.Meteorol. 95: 67-84.

Egilla, J.N., Davies, F.T. Jr. \& Malcom, C.D. 2001 . Effect of potassium on drought resistance of Hibiscus rosa-sinensis cv. Leprechaun: Plant growth, leaf macro- and micronutrient content and root longevity. Plant Soil 229: 213-224.

Escudero, A., García, B., Gómez, J.M. \& Luis, E. 1985. The nutrient cycling in Quercus rotundifolia and Q. pyrenaica ecosystems of Spain. Oecol. Plant. 6: 73-86.

Flores, J. \& Jurado, E. 2003. Are nurse-protégé interactions more common among plants from arid environments? $J$. Veg. Sci. 14: 911-916.

Franco, A.C. \& Nobel, P.S. 1988. Interactions between seedlings of Agave deserti and the nurse plant Hilaria rigida. Ecology 69: 1731-1740.

Gallardo,A. 2001. Descomposición de hojarasca en ecosistemas mediterráneaos. In: Zamora, R. \& Pugnaire, F.I. (eds.) Ecosistemas mediterráneaos. Análisis funcional, pp. 95124. Textos Universitarios 32, AEET-CSIC, Madrid, ES.

Gómez, J.M. 2004. Importance of burial and microhabitat on Quercus ilex early recruitment: non-additive effects on multiple demographic processes. Plant Ecol. 172: 287-297.

Gómez-Aparicio, L., Zamora, R., Gómez, J.M., Hódar, J.A., Castro, J. \& Baraza, E. 2004. Applying plant facilitation to forest restoration in Mediterranean ecosystems: a metaanalysis of the use of shrubs as nurse plants. Ecol. Appl. 14: 1128-1138.

Gómez-Aparicio, L., Zamora, R. \& Gómez, J.M. 2005. Regeneration status of the endangered Acer opalus subsp. granatense throughout its geographical distribution in the Iberian peninsula. Biol. Conserv. 121: 195-206.

Greenlee, J.T. \& Callaway, R.M. 1996. Abiotic stress and the relative importance of interference and facilitation in montane bunchgrass communities in western Montana. Am. Nat. 148: 386-396.

Hjältén, J. \& Price, P.W. 1997. Can plants gain protection from herbivory by association with unpalatable neighbours? A field experiment in a willow-sawfly system. Oikos 78: 317322.

Holmgren, M., Scheffer, M. \& Huston, M.A. 1997. The interplay of facilitation and competition in plant communities. Ecology 78: 1966-1975.

Huesca, M., Cortina, J. \& Bellot, J. 1998. Soil fertility as affected by gorse (Ulex parviflorus). In: Viegas, D.X. (ed.) Forest fire research, pp. 1643-1652. Coimbra, PT.

Jackson, L.E., Strauss, R.B., Firestone, M.K. \& Bartolome, J.W. 1990. Influence of tree canopies on grassland productivity and nitrogen dynamics in deciduous oak savanna. Agr. Ecosyst. Environ. 32: 89-105.

Joffre, R. \& Rambal, S. 1993. How tree cover influences the water balance of Mediterranean Rangelands. Ecology 74: 570-582.

Kitzberger, T., Steinaker, D.F. \& Veblen, T.T. 2000. Effects of climatic variability on facilitation of tree establishment in northern Patagonia. Ecology 81: 1914-1924.

Maestre, F.T., Bautista, S., Cortina, J. \& Bellot, J. 2001. Potential for using facilitation by grasses to establish shrubs on a semiarid degraded steppe. Ecol. Appl. 11: 1641-1655.

Maestre, F.T., Bautista, S. \& Cortina, J. 2003. Positive, nega- tive, and net effects in grass-shrub interactions in Mediterranean semiarid grasslands. Ecology 84: 3186-3197.

Molero-Mesa, J., Pérez-Raya, F. \& Valle, F. 1992. Parque Natural de Sierra Nevada: paisaje, fauna,flora, itinerarios. Rueda, Madrid, ES.Moro, M.J., Pugnaire, F.I., Haase, P. \& Puigdefábregas, J. 1997. Effect of the canopy of Retama sphaerocarpa on its understorey in a semiarid environment. Funct. Ecol. 11: 425-431.

Niering, W.A., Whittaker, R.H.\& Lowe, C.H. 1963. The saguaro: a population in relation to its environment. Science 142: 1523.

Pearcy, R.W., Ehleringer, J., Mooney, H.A. \& Rundel, P.W. 1989. Plant physiological ecology. Field methods and instrumentation. Chapman \& Hall, NY, US.

Pugnaire, F.I., Haase, P., Puigdefábregas, J., Cueto, M., Clark, S.C. \& Incoll, L.D. 1996. Facilitation and succession under the canopy of a leguminous shrub, Retama sphaerocarpa, in a semi-arid environment in south-east Spain. Oikos 76: 455-464.

Rebollo, S., Milchunas, D.G., Noy-Meir, I. \& Chapman, P.L. 2002. The role of a spiny plant refuge in structuring grazed shortgrass steppe plant communities. Oikos 98: 53-64.

Rudgers, J.A. \& Maron, J.L. 2003. Facilitation between coastal dune shrubs: a non-nitrogen fixing shrub facilitates establishment of a nitrogen-fixer. Oikos 102: 75-84.

Scholes, R.J. \& Archer, S.R. 1997. Tree-grass interactions in savannas. Annu. Rev. Ecol. Syst. 28: 517-544.

Shumway, S.W. 2000. Facilitative effects of a sand dune shrub on species growing beneath the shrub canopy. Oecologia 124: $138-148$.

Soriano, A. \& Sala, O.E. 1986. Emergence and survival of Bromus setifolius in different microsites of a Patagonian arid steppe. Isr. J. Bot. 35: 91-100.

Stokes, M.E., Davis, C.S.\& Koch, G.G. 1995. Categorical data analysis using the SAS System. SAS Institute, Cary, NC, US.

Tirado, R. 2003. Interacciones positivas entre plantas: mecanismos y consecuencias. Ph.D. Thesis, University of Sevilla, ES.

Valiente-Banuet, A. \& Ezcurra, E. 1991. Shade as a cause of association between the cactus Neobuxbaumia tetetzo and the nurse plant Mimosa luisana in the Tehuacán Valley, Mexico.J. Ecol. 79: 961-971.

Valiente-Banuet, A., Vite, G.F. \& Zavala-Hurtado, A. 1991. Interaction between the cactus Neobuxbaumia tetetzo and the nurse shrub Mimosa luisana.J. Veg. Sci. 2: 12-14.

van den Driessche, R. 1991. Effects of nutrients on stock performance in the forest. In: van den Driessche (ed.) Mineral nutrition in conifer seedlings, pp. 229-260. CRC Press, Boca Ratón, FL, US.

Wahl, M. \& Hay, M.E. 1995. Associational resistance and shared doom: effect of epibiosis on herbivory. Oecologia 102: 329-240.
Received 17 September 2004; Accepted 7 February 2005. Co-ordinating Editor: E. Ezcurra. 